\title{
Relationship Between Learning Style With Student Learning Outcomes on Structure and Function of Plants
}

\author{
Elma Nur Hidayati ${ }^{\text {a*}}$, Ara Hidayat ${ }^{\text {a }}$, Ukit ${ }^{\text {a }}$ \\ ${ }^{a}$ Faculty of Tarbiyah and Teacher Training, UIN Sunan Gunung Djati, Bandung, Indonesia \\ elmanh74@gmail.com*; arahidayat@uinsgd.ac.id; ukit21@uinsgd.ac.id
}

\begin{abstract}
Article Info
Article history:

Received Aug 28, 2021

Revised Oct 28, 2021

Accepted Oct 28, 2021

\section{Keywords:}

Learning Style

Learning Outcomes

Structure and Function of Plants

ABSTRACT

Learning styles can make students learn easily, fun, meaningfully that will improve their learning outcomes. This study aimed to determine the correlation between learning styles and student's learning outcomes in online learning about structure and function of plant. The correlation test method was used and samples were chosen using simple random sampling, consisting of 68 students in class VIII SMPN 2 Pangkalpinang. The data were collected using interview, questionnaire, documentation methods, and analyzed by Pearson product moment correlation test. The results showed that about $72 \%$ students in class VIII SMPN 2 Pangkalpinang tended to have a visual learning style and $75 \%$ with completed learning-outcomes. The correlation test indicated that there was no significant relationship between learning styles and their learning outcomes, by evidence and determination value of $0.111>0.05$ and $3.8 \%$ simultaneously. There is no correlation between learning styles and learning outcomes, presumably because learning styles only contribute $3.8 \%$ in which other $96.2 \%$ were determined by other factors such as teacher motivation and teaching strategies. However, although there is no correlation, learning styles still contribute to student's learning success. Therefore, it is necessary to conduct further research related to other factors that may affect student learning outcomes.
\end{abstract}

This is an open access article under the CC BY-SA license.

\section{Introduction}

Online learning in the realm of Indonesian education during this pandemic is a policy taken by the government in an effort to prevent the spread of the corona virus that is endemic throughout the world. The online learning system is seen as one of the effective ways to stop or prevent the corona virus (Rohmadani, 2020).

Online learning is one type of learning that is carried out on the Internet, where teachers and students cannot communicate directly and face to face. This learning can be done anytime and anywhere, depending on the availability of the supporting tools used (Pohan, 2020).

The presentation of material in online learning is generally uniform and students with different learning styles are given the same treatment, so learning is less than optimal, because not all students can receive the material presented well. Therefore, it is very 
important for teachers to pay attention to the learning styles of each student, as in the presentation of material it must be based on the student's learning style (Chulaelah, 2017).

Learning style is a way for students to focus on the process, and understand difficult and new information with different perceptions (Ghufron \& Risnawita, 2013). In simple terms, learning styles are divided into three, namely: (a) visual learning style, it is easier to capture information when learning in visual form; (b) auditory learning style, learning through listening (c) kinesthetic learning style, more comfortable learning in an active and interactive way (Asrori, 2007).

Manalu et al (2019) stated that students who know or optimize their learning styles can focus more on receiving and processing information in learning, so they can work on questions and obtain good learning outcomes in the future. Therefore, it is necessary to understand and optimize learning styles in the learning process and student learning in order to improve student learning outcomes.

According to Yusuf (2014) student learning outcomes are a benchmark that describes student achievement and symbolizes the success of teachers in teaching. One of the factors that influence student learning outcomes is the individual uniqueness of each student, namely learning style (Ghufron \& Risnawita, 2013).

Learning style is one of the factors that influence student learning success. This learning style can make students learn easily, interestingly and meaningfully, so as to obtain good learning outcomes (Manalu et al., 2019). Therefore, it is important to know students' learning styles in the learning process.

Initial information obtained from a science teacher for class VIII at SMP Negeri 2 Pangkalpinang explained that the teacher knew that each student had a different learning style, but had not yet identified each student's learning style. In addition, student learning outcomes in science lessons, especially biology, it is known that there are still some students who have not achieved the KKM score of 75.

Some students have low science (Biology) learning outcomes because they do not know or optimize their learning styles. As Manalu et al (2019) stated that students with good learning styles will be able to work on questions and get good learning outcomes, while students who do not know or optimize their learning styles will get poor learning outcomes.

In this study, the material applied was the structure and function of plants. This material is listed in the 2013 curriculum competency standards for science lessons, which are taught in the odd semester of class VIII at the junior high school level. The basic competencies listed in the material on plant structure and function are: 3.4 Analyzing the relationship between plant tissue structures and their functions, as well as technologies inspired by plant structures. 4.4 Presenting work from the results of searching various sources of information on technology inspired by observations of plant structures. This material can be studied by students online with the help of the Google Classroom application at home using their respective learning styles (both visual, auditory, and kinesthetic learning styles), so that students can more easily learn and understand the material on the structure and function of plants so that they can achieve their goals. mastery of expected learning outcomes. Based on the above background, it is necessary to conduct research on "The Relationship between Learning Styles and Student Learning Outcomes on the Material Structure and Function of Plants".

Based on the background that has been stated above, several problems can be formulated, namely, How are student learning styles, student learning outcomes, the relationship between student learning styles and learning outcomes. This study aims to determine the relationship between learning styles and learning outcomes of class VIII 
students of SMP Negeri 2 Pangkalpinang. One of the relevant studies that can be used as a reference in this research is the research conducted by Nurlia et al (2017) which shows the results of research that there is a strong and real relationship between learning styles and learning outcomes in biology, this can be seen from the value of the correlation coefficient ( r) obtained is 0.665 with a significance value of 0.000 . Therefore, the hypothesis that can be taken in this study is that there is a significant relationship between student learning styles and student learning outcomes in online learning of plant structure and function materials.

\section{Method}

The research method used in this research is correlation. The population in this study is class VIII students at SMPN 2 Pangkalpinang which consists of 8 classes with a total of 274 students. Sampling was done by using Simple Random Sampling technique. The selected research subjects were students of class VIII-F with a total of 34 students and VIII-G with a total of 34 students. The instruments used in this research are interview format, student learning style questionnaire, and documentation of student learning outcomes. The data obtained were then analyzed using normality test, linearity test, correlation test, and coefficient of determination test.

\section{Results and Discussion}

The results of the categorization of student learning styles showed that the dominant learning style in SMPN 2 Pangkalpinang students was the visual learning style by $72 \%$. The data on the results of the student learning style categories can be seen in Table 1 below.

Table 1. Frequency Distribution of Student Learning Styles

\begin{tabular}{clcc}
\hline No & Category Learning Style & The number of students & Percentage \\
\hline 1 & Visual & 49 & $72 \%$ \\
2 & Auditorial & 9 & $13 \%$ \\
3 & Kinesthetic & 10 & $15 \%$ \\
& Amount & 68 & $100 \%$ \\
\hline
\end{tabular}

Based on Table 1, the most common learning style of VIII grade students of SMPN 2 Pangkalpinang in online learning of plant structure and function is visual learning style, with a total of 49 students $(72 \%)$. These results are in line with the research conducted by Irawati et al (2021), namely many students have a visual learning style of $47.14 \%$, students with a kinesthetic learning style are slightly $27.14 \%$, and very few students have an auditory learning style that is equal to $25,72 \%$.

Factors that support the causes of visual learning styles are mostly owned by class VIII students at SMPN 2 Pangkalpinang, namely the characteristics of the material structure and function of plants that require students to know and understand various structures and tissues in plants so that students are more likely to use visuals in learning. In addition, based on information obtained from class VIII science teachers at SMP Negeri 2 Pangkalpinang that in delivering material on the structure and function of plants, teachers use PPT as additional learning material for students sent by the teacher through Google Classroom, which students are then asked to read or study the material. Reading activities require students to tend to use their visual senses when studying the structure and function of plants. In addition, the use of power point media is also more effectively used by students with visual learning styles (Nurwidayanti \& Mukminan, 2018). According to Subekti \& Taram (2021), Google 
Classroom-assisted online learning can be used for students with visual learning styles because it shows effective results, but not for students with auditory and kinesthetic learning styles.

Students with visual learning styles are more dominant in using their eyes or vision in learning (Wood, 2000). There are several online learning media that can be used by visual students such as educational websites (Sasmito et al., 2014) and learning houses (Kurnia \& Suhartini, 2021) because the learning resources presented are in the form of text, images, videos, animations, which can be used by students. visual. As stated by Uno (2012) students with visual learning styles can use graphic devices in studying learning materials, such as films or videos, pictures or illustrations.

For auditory learning style, the results showed that only 9 students $(13 \%)$ had auditory learning style. According to Sutiah (2016), students with this learning style learn by listening. Students with auditory learning styles enjoy learning delivered through discussions, lectures, interviews, and video recordings (Pritchard, 2009). There are several online media that auditory students can use, such as You Tube (Bargi, 2019) or the Zenius application, because this application provides discussion of learning materials in the form of videos (Nurfitriana \& Zulfah, 2020), and utilizes the WhatsApp or Zoom application as a medium for discussion with the teacher. or friends (Wilson, 2020).

Uno (2012) said that the kinesthetic learning style is a learning style that remembers it by touching something that can provide that information. From the results of the study, it was found that 10 students (15\%) had a kinesthetic learning style. There are several online media that kinesthetic students can use, such as studying plant structure and function by using learning videos with demonstration techniques on You Tube (Halawa, 2021) and using the Quizlet application to study plant structure and function while playing (Sari, 2019). As said by Uno (2012), the learning approach that can be used for kinesthetic students is to learn through experience from various models or demonstrations, do practicum in the laboratory or play while learning.

Each indicator of student learning style is analyzed to determine the average value obtained on each indicator. The results of the analysis are shown in Figure 1 as follows.

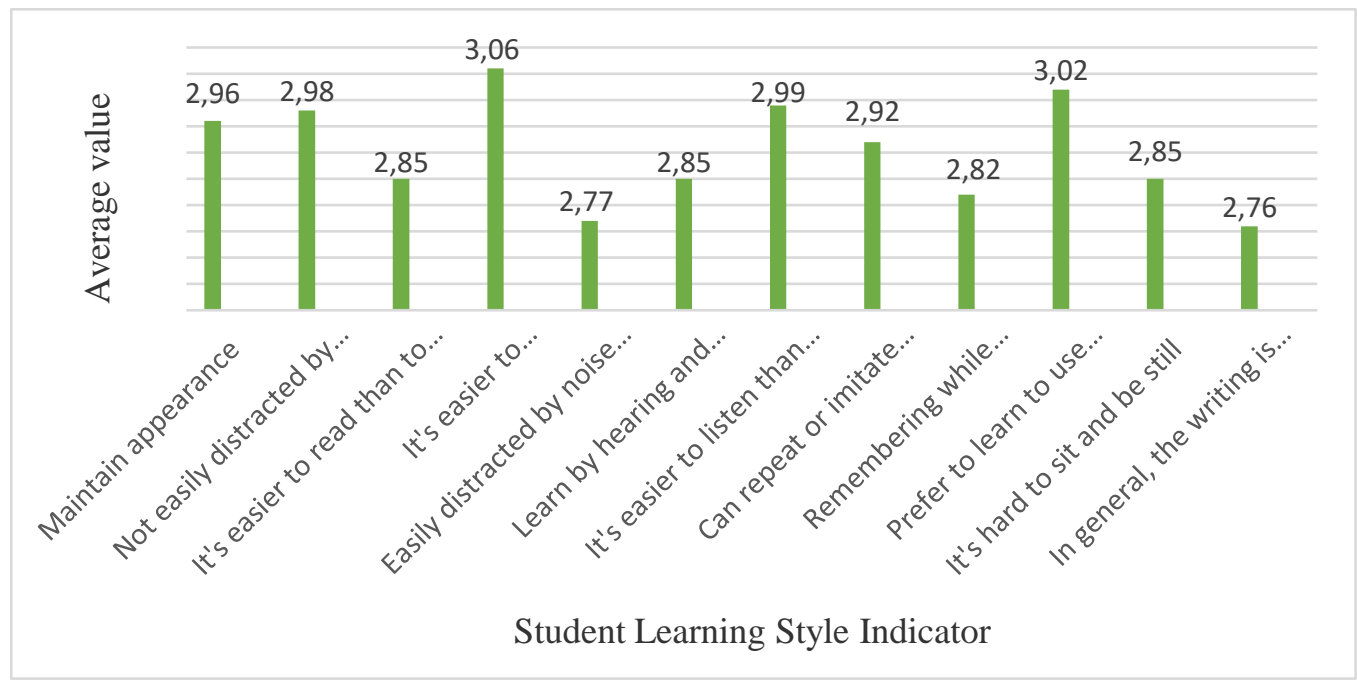

Figure 1. Learning Style Indicator Graph

Based on Figure 1, data on student learning styles were obtained covering 12 indicators consisting of four indicators of visual learning style, four indicators of auditory learning 
style, and four indicators of kinesthetic learning style. The results of the analysis of each indicator will be explained below.

\section{Visual Learning Style Indicator}

1) Maintain appearance

Maintaining appearance has an average of 2.96 in the high category (Figure 1). This shows that when studying the structure and function of plants online, grade VIII students of SMPN 2 Pangkalpinang who have a visual style of learning really take care of their appearance. They wear neat clothes when studying online at home. As stated by Daik et al (2020), students with visual learning styles always prioritize appearance in terms of clothing or overall appearance.

2) Not easily distracted by noise

The average value of the indicator not easily disturbed by noise is 2.98 in the high category. This shows that in online learning the structure and function of plants in class VIII SMPN 2 Pangkalpinang with visual learning styles are not easily distracted by noise. Even though there was a commotion, they could still learn. As stated by Senjaya et al (2017), that when studying, students with a visual learning style will not be disturbed by disturbances or commotion around the house.

3) It is easier to read than to be read

The indicator that it is easier to read than read has an average of 2.85 in the high category. This means that grade VIII students of SMPN 2 Pangkalpinag with visual learning styles prefer to read on their own the material on the structure and function of plants. As stated by Sulisawati et al (2019), visual students understand the subject matter through reading.

4) It's easier to demonstrate than to explain

The indicator who prefers to demonstrate rather than explain has an average of 3.06 in the high category, which indicates that visual learning style students of class VIII SMPN 2 Pangkalpinang, when online learning about plant structure and function, they prefer to demonstrate rather than explain (Figure 1). Visual students prefer to demonstrate because visual students have problems in direct dialogue, it is difficult to explain things to others (Mustafida, 2013).

\section{Auditorial Learning Style}

1) Easily distracted by noise or noise

The indicator of being easily disturbed by noise or noise is 2.77 with a high category (Figure 1). This shows that when studying the structure and function of plants online, class VIII SMPN 2 Pangkalpinang students with auditory learning styles will feel disturbed in their studies when there is sound or noise, so they cannot concentrate in studying. Papilaya \& Huliselan (2016) suggest that students with auditory learning styles cannot focus on learning when there is a commotion, and cannot even focus on learning when there is music playing at a large volume. This is because auditory students are more likely to use their ears as a medium of learning, so that if there are other sounds, they will not be able to focus on learning.

2) Learn by hearing and remembering what was discussed rather than what was seen The average indicator of learning through hearing and remembering what was discussed rather than seen was 2.85 in the high category. This shows that the eighth grade students of SMPN 2 Pangkalpinang with an auditory learning style, when studying the structure and function of plants online will master and understand the lessons communicated 
orally or through discussion. Pramesti \& Ratnadi (2020) stated that students with auditory learning styles rely on hearing to understand and remember subject matter, and students with auditory learning styles really enjoy listening to what others have to say.

3) It's easier to listen than read

The indicator of listening more than reading has an average of 2.99 in the high category (Figure 1). This means that the eighth grade students of SMPN 2 Pangkalpinang who have an auditory learning style prefer listening to material descriptions than reading material when studying plant structures and functions online. This is because auditory students have difficulty understanding the concept of written form (Restianim et al., 2020). Daik et al (2020) stated that if the learning material is read by other people (be it friends or teachers), the auditory students will feel very happy.

4) Can repeat or imitate tone, rhythm, and tone of voice

The indicator that can repeat or imitate tone, rhythm, and voice color has an average of 2.92 in the high category, which indicates that grade VIII students of SMPN 2 Pangkalpinang with auditory learning styles can repeat or imitate other people's speech styles (Figure 1). They can use the same intonation to explain the material structure and function of plants that they hear again. As stated by Novitasari \& Fauziddin (2021), auditory students have the ability to imitate, remember and repeat the sounds they hear, not only hear them.

\section{Kinesthetic Learning Style}

1) Remembering while walking and looking

The average score of the walking and viewing memory indicator was 2.82 in the high category (Figure 1). This shows that grade VIII students of SMPN 2 Pangkalpinang with kinesthetic learning styles are quicker to memorize/remember plant structure and function by walking and seeing objects directly. Restianim et al (2020) suggest that students with kinesthetic learning styles are easy to remember by observing body or physical movements while walking and practicing.

2) Prefer to learn to use physical movement

Indicators preferring to learn to use physical movements have an average of 3.02 in the high category. This shows that the kinesthetic students of class VIII SMPN 2 Pangkalpinang are happy to learn about the structure and function of plants by involving them physically. As stated by Mustafida (2013), the type of kinesthetic learner tends to receive and process information easily through a series of activities that can move part/all of the body and practice what has been learned. Likewise, Syofyan (2018) suggests that kinesthetic students learn through movement, they need to take action to enter information into the brain.

3) It's hard to sit and be still

The indicator of difficulty sitting and staying still has an average of 2.85 in the high category, which shows that grade VIII students of SMPN 2 Pangkalpinang with a kinesthetic learning style cannot sit still at their desks while studying material on the structure and function of plants online at home (Figure 1 ). As stated by Riduwan \& Rosdiana (2017) that students who have a kinesthetic learning style when studying will certainly not last long sitting in the same place. Mustafida (2013) also suggests that it is difficult for kinesthetic type learners to stay alone for several hours because students have a strong desire to be active.

4) Generally the writing is not good 
The indicators are generally not well written, with an average of 2.76 in the high category (Figure 1). This means that grade VIII students of SMPN 2 Pangkalpinang with a kinesthetic learning style have poor writing. Senjaya et al (2017) stated that kinesthetic students are used to taking notes untidy and poorly written. Likewise, Setiana (2020) states that kinesthetic student writing is difficult for people to understand (bad).

Student learning outcomes were grouped based on the KKM value for science learning at SMP Negeri 2 Pangkalpinang and the following data were obtained.

Table 2. Frequency Distribution of Learning Outcomes Trends

\begin{tabular}{cccccc}
\hline No & Value Interval & Frequency & Percentage & Interpretation & Category \\
\hline 1 & $\mathrm{Y}>75$ & 51 & $75 \%$ & Complete & Tall \\
2 & $\mathrm{Y}<75$ & 17 & $25 \%$ & Not Complete & Low \\
& Amount & 68 & 100 & & \\
\hline
\end{tabular}

Data on student learning outcomes of class VIII SMPN 2 Pangkalpinang showed that there were 51 students who completed with a percentage of $75 \%$ and 17 students did not complete with a percentage of $25 \%$ (Table 2). Because the percentage of students who complete is $75 \%$, student learning outcomes are classified in the high category, namely in the range of 61-80 (Riduwan, 2010). This shows that students have mastered the material structure and function of plants well. As stated by Nurlia et al (2017: 324) that student learning outcomes in the high category indicate that students have mastered the lesson well.

The structure and function of plants according to Nurhasikin et al (2019) and Andriyani et al (2020) are basically material that is classified as difficult for students to understand. This is because there are many concepts that must be remembered and understood, as well as the need for a microscope that is either used or the results of observations are difficult for most students to understand. This is also reinforced by information obtained from a science teacher for class VIII of SMPN 2 Pangkalpinang which indicates that the material on the structure and function of plants is material that is quite difficult for students to understand.

The ability of class students to master the material structure and function of plants online, of course, is influenced by several factors, one of which is the internal factor, namely the uniqueness of the individual, namely the learning style. Prashnig (2007) states that the key to successful student learning is knowing their learning style. As Manalu et al (2019) stated that when students recognize and optimize their learning styles, students can receive, absorb, and process information obtained in the learning process, so that later it will have an impact on good student learning outcomes as well.

The results of statistical tests showed that there was no significant relationship between learning styles and learning outcomes for class VIII students of SMPN 2 Pangkalpinang. This is indicated by a significance value of $0.111>0.05$. The data from the statistical analysis can be seen in Table 3 below.

Table 3. Statistical Analysis Test Results

\begin{tabular}{ccc}
\hline \multirow{3}{*}{ Dormality } & \multicolumn{2}{c}{ Data Analysis } \\
\cline { 2 - 3 } & Information & 0,595 \\
\hline \multirow{3}{*}{ Linearity } & $\mathrm{F}_{\text {Count }}$ & Normal \\
\cline { 2 - 3 } & $\mathrm{F}_{\text {Table }}$ & 0,793 \\
\cline { 2 - 3 } & Information & 1,89 \\
\hline Correlation Test & $\mathrm{R}_{\text {Count }}$ & Linear \\
\cline { 2 - 3 } & $\mathrm{R}_{\text {Table }}$ & 0,195 \\
\cline { 2 - 3 } & $\mathrm{Sig}$ & 0,244 \\
\cline { 2 - 3 } & & 0,111 \\
\hline
\end{tabular}




\begin{tabular}{ccc}
\hline & Information & $\begin{array}{c}\mathrm{H}_{\mathrm{a}} \text { is } \\
\text { rejected, } \mathrm{H}_{0} \\
\text { is accepted }\end{array}$ \\
\hline $\begin{array}{c}\text { Coefficient of } \\
\text { Determination }\end{array}$ & Results & $3,8 \%$ \\
\hline
\end{tabular}

The results of the analysis of the relationship between learning styles and online learning outcomes of plant structure and function materials obtained a correlation value (r) of 0.195 with a significance value of 0.111 (Table 3). If seen in the interpretation table of the correlation coefficient according to Lestari \& Yudhanegara (2018), 0.195 is included in the very weak category so that the correlation is ignored (it is considered that there is no correlation between the $\mathrm{X}$ variable and $\mathrm{Y}$ variable), and if it is seen from the significant value $0.111>0.05$ then it can be concluded it was concluded that there was no significant relationship between learning styles and online learning outcomes for plant structure and function (Purnomo, 2016). This study was similarly conducted by Mite, et al (2016: 825) which showed that there was no relationship between learning styles and student learning outcomes, with a significant value of $0.178>0.05$. Likewise, what was done by Putri et al (2020) which showed that there was no significant relationship between learning styles and student learning outcomes, with a significant value ( $p$-value) of $0.744>0.05$.

The results of this study are not in line with previous studies that examined the relationship between learning styles and learning outcomes such as those conducted by Manalu et al (2019) and also by Putri et al (2019) which stated that there was a positive and significant relationship between learning styles and student learning outcomes.

The reason that there is no relationship between learning styles and student learning outcomes can be seen from several sides, namely: teachers, students, and errors in research. In the teacher aspect, the teacher does not use strategies that are suitable for all the diverse characteristics of students, this is because the teacher does not know the child's learning style. In the student aspect, students do not apply their respective learning styles, this is because students do not know the type of learning style (Chania et al., 2016). Meanwhile, when viewed from the error aspect in the study, the researcher did not analyze how students learn and did not analyze the teacher's strategies in the local area (Putri et al., 2020).

The limitations in this study are that this research is an Ex Post Facto study, namely research if certain variable treatment or manipulation has occurred previously, so there is no need to give further treatment to these variables and whatever the results of the research do not need to be given further treatment of the variables (Chania et al., 2016). So the results of this study do not support the researcher's hypothesis. In addition, as said Putri et al (2020) in this study should use path analysis, while in this study did not use path analysis. So, for future research, path analysis can be used so that the results obtained are clearer.

The insignificant relationship between learning styles and student learning outcomes in online learning of plant structure and function material is because there are other factors that influence it, including the students' own internal factors (besides student learning styles as internal factors). As it is known that the coefficient of determination of research results is $3.8 \%$ so it can be concluded that the contribution of learning styles to learning outcomes is $3.80 \%$, while $96.2 \%$ is influenced by other factors not examined by researchers. These other factors include talent, motivation, student attitudes, health, learning environment conditions, and so on (Syarifuddin et al., 2010). In addition, the teacher's strategy in teaching can also influence, because it could be that when learning takes place the teacher does not pay attention to the student's learning style, so the teacher does not provide a strategy that is in accordance with their learning style, so that it can have an impact on student learning 
outcomes. Because if given a strategy that suits their learning style, students can develop better (Thobroni, 2015).

\section{Conclusion}

Based on the results of research on the relationship between learning styles and student learning outcomes in online learning material on the structure and function of class VIII plants at SMP Negeri 2 Pangkalpinang, it shows that the learning style that tends to be owned by class VIII students at SMPN 2 Pangkalpinang is visual learning style, which is $72 \%$ of students, while the category of auditory learning style is $13 \%$ of students, and the category of kinesthetic learning style is $15 \%$ of students. As for student learning outcomes in online learning of plant structure and function, students who achieve learning completeness are $75 \%$ in the high category. Based on the significance value of the correlation calculation results of $0.111>0.05$, then $\mathrm{Ha}$ is rejected and $\mathrm{H} 0$ is accepted. So that in this research there is no significant relationship between student learning styles and online learning outcomes of plant structure and function material for class VIII SMPN 2 Pangkalpinang with a correlation value of 0.195 .

\section{References}

Andriyani, F., Saraswati, R. R., Melasari, D., Putri, A., \& Sumardani, D. (2020). Kelayakan Media Pembelajaran Monopoli pada Materi Struktur dan Fungsi Jaringan Tumbuhan. Risenologi (Jurnal Sains, Teknologi, Sosial, Pendidikan, Dan Bahasa), 5(1), 20-24. https://doi.org/https://doi.org/10.47028/j.risenologi.2020.51.60

Asrori, M. (2007). Psikologi Pembelajaran. Bandung: CV. Wacana Prima.

Bargi. (2019). Efektivitas Metode Discovery dan Media Youtube Terhadap Siswa Kelas V SD N Tlahap Dalam Materi Fotosintesis. Proceeding of Biology Education, 3(1), 121-133. https://doi.org/10.21009/pbe.3-1.15

Chania, Y., Haviz, M., \& Sasmita, D. (2016). Hubungan Gaya Belajar dengan Hasil Belajar Siswa pada Pembelajaran Biologi Kelas X SMAN 2 Sungai Tarab Kabupaten Tanah Datar. Journal of Sainstek, 8(1), 77-84. Retrieved from https://repo.iainbatusangkar.ac.id/xmlui/bitstream/handle/123456789/13350/15925 55667055_16. 2016 - Chania\%2C Haviz \%26 Sasmita Sainstek.pdf?sequence $=1 \&$ isAllowed $=\mathrm{y}$

Chulaelah, S. Y. (2017). Penerapan Metode E-learning Berdasarkan Gaya Belajar Siswa Pada Mata Pelajaran Fisika. Jurnal Komputer Terapan, 3(2), 241-250. https://doi.org/https://doi.org/10.35143/jkt

Daik, A. K. V, Abi, A. M., \& Bien, Y. I. (2020). Analisis gaya belajar matematika pada siswa kelas vii smp negeri oebaki. Range: Jurnal Pendidikan Matematika, 2(1), 1824. https://doi.org/https://doi.org/10.32938/jpm.v2i1.538

Ghufron, M. N., \& Risnawita, R. (2013). Gaya Belajar Kajian Teoritik. Yogyakarta: Pustaka Pelajar. 
Halawa, M. V. B. (2021). Efektivitas Pemanfaatan Platform Media Sosial dalam Pembelajaran Praktikum Secara Daring. Attractive: Innovative Education Journal, 3(1), 52-64. https://doi.org/http://dx.doi.org/10.51278/aj.v3i1.216

Irawati, I., Nasruddin, \& Ilhamdi, M. L. (2021). PENGARUH GAYA BELAJAR TERHADAP HASIL BELAJAR IPA. J. Pijar MIPA, 16(1), 44-48. https://doi.org/10.29303/jpm.v16i1.2202

Kurnia, N. S., \& Suhartini, R. (2021). Efektivitas rumah belajar bagi siswa smk. E-Jurnal Unesa, 10(1), 113-119. Retrieved from https://ejournal.unesa.ac.id/index.php/jurnal-tata-busana/article/view/38117

Lestari, K. E., \& Yudhanegara, M. R. (2018). Penelitian Pendidikan Matematika. Bandung: PT Refika Aditama.

Manalu, L. Y., Sutrisno, \& Hasanah, U. (2019). Hubungan gaya belajar dengan hasil belajar ilmu pengetahuan alam siswa kelas v sekolah dasar. Dinamika Sekolah Dasar, 1(1), 1-13. https://doi.org/doi.org/10.21009/DSD.XXX.

Mustafida, F. (2013). KAJIAN MEDIA PEMBELAJARAN BERDASARKAN KECENDERUNGAN GAYA BELAJAR PESERTA DIDIK SD/MI. Madrasah, 6(1), 77-96. https://doi.org/https://doi.org/10.18860/jt.v6i1.3291

Novitasari, Y., \& Fauziddin, M. (2021). Perkembangan Kognitif Bidang Auditori pada Anak Usia Dini. Jurnal Obsesi : Jurnal Pendidikan Anak Usia Dini, 5(1), 805-813. https://doi.org/10.31004/obsesi.v5i1.640

Nurfitriana, N., \& Zulfah, Z. (2020). Penerapan E-Learning dengan Aplikasi Zenius untuk Meningkatkan Motivasi Belajar Siswa SMP Negeri 2 Kampar Utara. Journal on Education, 3(1), 62-75. https://doi.org/https://doi.org/10.31004/joe.v3i01.342

Nurhasikin, Ningsih, K., \& Titin, T. (2019). PENGEMBANGAN MODUL BERBASIS DISCOVERY LEARNING MATERI STRUKTUR DAN FUNGSI JARINGAN TUMBUHAN SMA. Jurnal Pendidikan Informatika Dan Sains, 8(2), 163-178. https://doi.org/10.31571/saintek.v8.i2.1223

Nurlia, Hala, Y., Muchtar, R., Jumadi, O., \& Taiyeb, A. M. (2017). Hubungan Antara Gaya Belajar, Kemandirian Belajar, dan Minat Belajar dengan Hasil Belajar Biologi Siswa. Jurnal Pendidikan Biologi, 6(2), 321-328. https://doi.org/https://doi.org/10.24114/jpb.v6i2.6552

Nurwidayanti, D., \& Mukminan, M. (2018). Pengaruh Media Pembelajaran Terhadap Hasil Belajar Ekonomi Ditinjau Dari Gaya Belajar Siswa SMA Negeri. Harmoni Sosial: Jurnal Pendidikan IPS, 5(2), 105-114. https://doi.org/10.21831/hsjpi.v5i2.17743

Papilaya, J. O., \& Huliselan, N. (2016). IDENTIFIKASI GAYA BELAJAR MAHASISWA. Jurnal Psikologi Undip, 15(1), 56-63. https://doi.org/https://doi.org/10.14710/jpu.15.1.56-63 
Pohan, A. E. (2020). Konsep Pembelajaran Daring Berbasis Pendekatan Ilmiah. Purwodadi- Grobogan: CV Sarnu Untung.

Pramesti, N. M. I., \& Ratnadi, N. M. D. (2020). Pengaruh Kecerdasan Emosional, Gaya Belajar Visual, Gaya Belajar Auditorial Dan Kinestetik Pada Tingkat Pemahaman Akuntansi. E-JA e-Jurnal Akuntansie-Jurnal Akuntansi, 30(1), 130-146. https://doi.org/https://doi.org/10.24843/EJA.2020.v30.i01.p10

Prashnig, B. (2007). The Power of Learning Styles: Memacu Anak Melejitkan Prestasi dengan Mengenali Gaya Belajarnya. Bandung: Kaifa.

Pritchard, A. (2009). Ways of Learning: Learning Theories and Learning Styles in The Classroom Second Edition. New York: Routledge Taylor \& Francis Group.

Purnomo, R. A. (2016). Analisis Statistik Ekonomi dan Bisnis Dengan SPSS. Ponorogo: CV. Wade Group.

Putri, F. E., Amelia, F., \& Gusmania, Y. (2019). Hubungan Antara Gaya Belajar dan Keaktifan Belajar Matematika Terhadap Hasil Belajar Siswa. EDUMATIKA: Jurnal Riset Pendidikan Matematika, 2(2), 83-88. https://doi.org/https://doi.org/10.32939/ejrpm.v2i2.406

Putri, W. O. N., Rusnayati, H., \& Purwana, U. (2020). Hubungan Gaya Belajar dengan Hasil Belajar Siswa pada Materi Usaha dan Energi. Prosiding Seminar Nasional Fisika, 1(1), 108-114. Retrieved from http://proceedings2.upi.edu/index.php/sinafi/article/view/1254/1137

Restianim, V., Pendy, A., \& Merdja, J. (2020). GAYA BELAJAR MAHASISWA PENDIDIKAN MATEMATIKA UNIVERSITAS FLORES DALAM PEMAHAMAN KONSEP FUNGSI. SPEJ (Science and Phsics Education Journal), 3(2), 48-56. https://doi.org/https://doi.org/10.31539/spej.v3i1.990

Riduwan. (2010). Dasar-Dasar Statistik. Bandung: Alfabeta.

Riduwan, M., \& Rosdiana, L. (2017). KESESUAIAN GAYA BELAJAR SISWA DENGAN METODE PEMBELAJARAN GURU TERHADAP PEMAHAMAN KONSEP IPA SISWA SMP. E-Jurnal Unesa, 5(2), 67-72. Retrieved from https://ejournal.unesa.ac.id/index.php/pensa/article/view/18754/17115

Rohmadani, A. I. (2020). DAMPAK COVID 19 TERHADAP CARA BERPIKIR DALAM PEMBELAJARAN DARING: STUDI KASUS DI YOGYAKARTA. Edification, 3(1), 125-134. https://doi.org/https://doi.org/10.37092/ej.v3i1.224

Sari, D. E. (2019). QUIZLET: APLIKASI PEMBELAJARAN BERBASIS SMARTPHONE ERA GENERASI MILENIAL, 29(1), 9-15. https://doi.org/https://doi.org/10.23917/jpis.v29i1.8150

Sasmito, Y. A., Susilowati, S. M. E., \& Sukaesih, S. (2014). Pemanfaatan Website Edukatif dengan Pembelajaran Arias Pada Materi Struktur dan Fungsi Jaringan Tumbuhan. 
Unnes Journal of Biology Education, 3(2), 238-246. https://doi.org/https://doi.org/10.15294/jbe.v3i2.4465

Senjaya, A. J., Sudirman, \& SW, P. E. (2017). ANALISIS GAYA BELAJAR SISWA TUNAGRAHITA RINGAN MATERI PERKALIAN DI SEKOLAH DAN DI RUMAH. Journal of Medives, 1(1), 1-8. Retrieved from http://ejournal.ivet.ac.id/index.php/matematika/article/view/451/524

Setiana. (2020). PENGARUH GAYA BELAJAR TERHADAP PRESTASI BELAJAR SISWA. Jurnal Fakultas Keguruan \& Ilmu Pendidikan, 1(1), 50-58. Retrieved from https://media.neliti.com/media/publications/332479-pengaruh-gaya-belajarterhadap-prestasi-511748a3.pdf

Subekti, Y. F., \& Taram, A. (2021). Pembelajaran Daring Matematika Berbantuan Google Classroom Ditinjau dari Gaya Belajar pada Masa Pandemi. Jurnal Pendidikan Matematika, 09(03), 333-342. https://doi.org/http://dx.doi.org/10.23960/mtk/v9i3.pp333-342

Sulisawati, D. N., Lutfiyah, \& Sukma, L. (2019). Identifikasi Modalitas Belajar VAK Kombinasi Siswa Dalam Pelajaran Matematika SMP Negeri 1 Arjasa Jember. Prismatika. Jurnal Pendidikan Dan Riset Matematika, 2(1), 32-42. Retrieved from http://ejurnal.budiutomomalang.ac.id/index.php/prismatika/article/view/572

Sutiah. (2016). Teori Belajar dan Pembelajaran. Sidoarjo: Nizamia Learning Center.

Syarifuddin, \& Dkk. (2010). Strategi Belajar Mengajar. Jakarta: Diadit Media.

Syofyan, H. (2018). ANALISIS GAYA BELAJAR DAN MOTIVASI BERPRESTASI TERHADAP HASIL BELAJAR IPA. Jurnal Eduscience, 3(2), 76-85. Retrieved from https://www.esaunggul.ac.id/wp-content/uploads/2018/02/4.-Analisis-GayaBelajar-Dan-Motivasi-Berprestasi-Terhadap-Hasil-Belajar-IPA.pdf

Thobroni. (2015). Belajar dan Pembelajaran. Yogyakarta: Ar-Ruzz Media.

Uno, H. B. (2012). Orientasi Baru Dalam Psikologi Pembelajaran. Jakarta: PT Bumi Aksara.

Wilson, A. (2020). PENERAPAN METODE PEMBELAJARAN DARING (ONLINE) MELALUI APLIKASI BERBASIS ANDROID SAAT PANDEMI GLOBAL. SAP (Susunan Artikel Pendidikan), 5(1), 66-72. Retrieved from https://journal.lppmunindra.ac.id/index.php/SAP/article/view/6386/3219

Wood, G. (2000). How To Study Second Edition. New York: Learning Experess.

Yusuf, M. (2014). Metode Penelitian: Kuantitaif, Kualitatif, dan Penelitian Gabungang. Jakarta: Prenadamedia Group. 